\title{
The Effect of the Covid-19 Pandemic on Traumatic and Non-traumatic Orthopedic Practice in a Tertiary Care Center: A Descriptive Cross-Sectional Study
}

\author{
Ücüncü Basamak Bir Hastanede Covid-19 Pandemisinin Travmatik ve Travmatik Olmayan \\ Ortopedik Hastalıklara Etkisi: Tanımlayıcı Kesitsel Çalıșma
}

\author{
Serdar Toy, Oktay Polat, Hakan Ozbay \\ Department of Orthopedics and Traumatology, Ağr Training and Research Hospital, Ağrı, Turkey
}

\begin{abstract}
Aim: Coronavirus (COVID-19) has emerged from Wuhan City, China, in 2019. Different precautions were taken in different territories and cities because of the diverse demographic structures of Turkey. In this study, the epidemiological prevalence of orthopedic traumatized and non-traumatized cases was assessed in a rural region of Turkey during the pandemic.
\end{abstract}

Material and Method: Between September 2019 and December 2020, 15452 patients were admitted to the clinic of orthopedics and traumatology with trauma, were evaluated in this retrospective cohort study. According to the dates of admission to the clinic, the patients were divided into pre-covid and covid groups. Age, gender, and fracture types of patients were recorded.

Results: 741 (4.8\%) patients were admitted to our clinic due to orthopedic trauma in the pre-covid period. In comparison, 816 (5.3\%) patients were admitted to our clinic due to the same problems in the covid period. There were statistically significant differences between groups in terms of gender $(p<0.001)$, age groups $(p<0.001)$, and the presence of orthopedic trauma $(p<0.001)$.

Conclusion: In rural areas, during the Covid-19 outbreak, the number of orthopedic trauma experienced increased compared to the previous period. Despite this, a decrease was observed in non-traumatic cases presenting to the outpatient clinic during the Covid-19 pandemic.

Key words: COVID-19; fracture; orthopedics; pandemic

\section{ÖZET}

Amaç: Coronavirüs (COVID-19), 2019 yılında Çin'in Wuhan șehrinde ortaya çıktı. Türkiye'nin farklı demografik yapıları nedeniyle farklı bölge ve șehirlerde farklı önlemler alındı. Bu çalıșmada, pandemi sırasında Türkiye'nin kırsal bir bölgesinde ortopedik travma geçirmiș ve travma geçirmemiș vakaların epidemiyolojik prevalansı değerlendirildi.
Materyal ve Metot: Bu geriye dönük kohort çalıșmasında Eylül 2019 ile Aralık 2020 tarihleri arasında ortopedi ve travmatoloji kliniğine bașvuran 15452 hasta değerlendirildi. Kliniğe bașvuru tarihlerine göre hastalar pre-covid ve covid gruplarına ayrıldı. Hastaların yaș, cinsiyet ve kırık tipleri kaydedildi.

Bulgular: Pre-covid döneminde $741(\% 4,8)$ hasta ortopedik travma nedeniyle kliniğimize bașvurmuștu. Buna karșılık $816(\% 5,3)$ hasta covid döneminde aynı sorunlardan dolayı kliniğimize bașvurmuștu. Gruplar arasında cinsiyet $(p<0,001)$, yaș grupları $(p<0,001)$ ve ortopedik travma varlığı $(p<0,001)$ açısından istatistiksel olarak anlamlı fark tespit edildi.

Sonuç: Kırsal kesimde Covid-19 salgını sırasında yașanan ortopedik travma sayısı bir önceki döneme göre artıș göstermiștir. Buna rağmen covid-19 pandemisi sırasında polikliniğe bașvuran travmatik olmayan vakalarda azalma gözlendi.

Anahtar kelimeler: Covid-19; kırık; ortopedi; pandemi

\section{Introduction}

Coronavirus (COVID-19) emerged from Wuhan City, China, in $2019^{1}$. After spreading worldwide, WHO announced the disease as a pandemic in March $2020^{2}$. Public health precautions like social isolation, social distancing, and curfew were promoted because of inefficiency in treatment to prevent the spreading of the virus ${ }^{3}$.

Our hospital is a tertiary care center located in Turkey's east and is the only hospital that accepts patients with Covid-19 and other diseases. Some precautions such

Iletișim/Contact: Serdar Toy, Department of Orthopedics and Traumatology, Ağr Training and Research Hospital, Ağrı, Turkey • Tel: 05057183926 • E-mail: serdartoy737@gmail.com • Geliș/Received:06.02.2021 • Kabul/Accepted:22.08.2021

ORCID: Serdar Toy, 0000-0001-8074-4672 • Oktay Polat, 0000-0001-7130-2434 • Hakan Özbay, 0000-0002-7319-0381 
as cancellation of elective surgeries and restrictions in outpatient clinics were taken to continue orthopedics and traumatology service.

This study investigates orthopedic traumatic and nontraumatic cases by comparing the lockdown period caused by the Covid-19 pandemic and the same period of the previous year to guide personal and source distribution to maintain health infrastructure.

\section{Materials and Methods}

Fifteen thousand and four hundred fifty-two patients admitted to orthopedics and traumatology clinics with trauma in September 2019 - December 2019 and September 2020 - December 2020 were evaluated in this retrospective cohort study. Ethical approval was obtained from the Ethics Committee of Ağri Training and Research Hospital (number: 17, date: 11.11.2020). Our hospital's electronic digital archive was used to evaluate traumatic and non-traumatic cases admitted to the emergency department or outpatient clinic. Patients who applied for administrative purposes and patients with missing files or inadequate information were excluded from this research. International Statistical Classification of Diseases and Related Health Problems (ICD) 10 codes were used to analyze the fracture types of patients. Fracture types of traumatic patients are divided into proximal, diaphysis, and distal 1/3 regions of long bones. Rare fracture types and fractures of flat bones were recorded as only names of fracture but not as proximal, diaphysis, and distal. Patients were categorized into four groups according to age as pediatric ( $<18$ years old), young adult ( 18 years old and older age -35 years old), middleaged (36-64 years old), and elderly (>64 years old). The patients were divided into two groups as pre-covid and covid periods, according to the date of admission to the clinic. The pre-covid group included patients admitted between September 2019 - December 2019 , and the covid group included patients admitted between September 2020 - December 2020. The gender of patients was recorded. All data were recorded and analyzed statistically.

\section{Statistical Analysis}

IBM SPSS Statistics 23.0 for statistical analysis (IBM Corp., Armonk, NY, USA) programs were used to evaluate the findings obtained in this study. Demographic data and others were reported as frequency and percentages. The arithmetic means \pm standard deviation was calculated for the numerical variables. The normalities of parameter distributions were assessed using Shapiro Wilk tests. Mann-Whitney U test and Student's t-tests were used to compare parameters between the two groups. Wilcoxon Signed-Rank tests were used for intragroup comparisons of non-normally distributed parameters. Pearson's chi-square test, Fisher's Exact tests, Fisher Freeman Halton test, and Yates Correction for Continuity were used to compare qualitative data. Significance was evaluated at $\mathrm{p}<0.05$.

\section{Results}

The number of patients was 10426 (67.50\%) in the pre-covid period, and the number of patients was 5026 (32.50\%) during the covid period. The mean age of the patients was $33.90 \pm 20.36$ (range: $0-110$ ). There were 8268 (53.50\%) male patients, and 7184 (46.50\%) were female. Thirteen thousand eight hundred ninety-five patients $(89.9 \%)$ applied with non-traumatic diseases, while $1557(10.1 \%)$ patients were admitted due to trauma. The age distribution of the patients was evaluated under four categories. The number of patients in the pediatric (range: $0-17$ ) group was 3495 (22.60\%); the number of patients in the young-adult (range: 1744) group was 7213 (46.70\%); the number of middleaged (range: $40-64)$ patients was 3316 (21.50\%); The number of patients in the elderly (range: 65-110) age group was 1428 (9.20\%) (Table 1).

There were 741 (4.8\%) patients who were admitted to our clinic due to orthopedic trauma in the pre-covid period (Fig. 1) and 816 (5.3\%) patients in the covid period (Fig. 2). The mean age of the patients admitted to our clinic due to orthopedic trauma in the pre-covid period was $23.82 \pm 18.96$ (range: 0-98). 506 (3.30\%) of the patients who applied due to orthopedic trauma in the pre-covid period were male, and 235 (1.50\%) were female. The average age of the patients admitted to our clinic due to orthopedic trauma during the covid period was $23.75 \pm 19.31$ (range: $0-97$ ). In the covid period, 561 (3.60\%) of the 816 patients who applied to our clinic due to orthopedic trauma were male, and $255(1.70 \%)$ were female (Table 2$)$.

A significant difference was found between the groups in terms of gender $(p<0.001)$. A statistically significant difference was found between the groups in terms of the age groups $(p<0.001)$. A significant difference was determined between the patients' admission periods and the presence of orthopedic trauma $(\mathrm{p}<0.001)$ (Table 3). 
Table 1. Distribution of age, gender and admission reason characteristics of patients in pre-covid and covid period

\begin{tabular}{|c|c|c|c|c|}
\hline & & \multicolumn{2}{|c|}{ Period } & \multirow[b]{2}{*}{$p$-value } \\
\hline & & $\begin{array}{l}\text { Pre-covid } \\
\text { Count n (\%) }\end{array}$ & $\begin{array}{c}\text { Covid } \\
\text { Count n (\%) }\end{array}$ & \\
\hline \multirow[t]{2}{*}{ Gender } & Male & $5323(34.4 \%)$ & 2945 (19.1\%) & $<0.001^{*}$ \\
\hline & Female & $5103(33.0 \%)$ & 2081 (13.5\%) & \\
\hline \multirow[t]{4}{*}{ Age groups } & Children & $2264(14.7 \%)$ & $1231(8.0 \%)$ & $<0.001^{*}$ \\
\hline & Young-adult & $4714(30.5 \%)$ & 2499 (16.2\%) & \\
\hline & Middle-aged & $2375(15.4 \%)$ & $941(6.1 \%)$ & \\
\hline & Elderly & 1073 (6.9\%) & 355 (2.3\%) & \\
\hline \multirow[t]{2}{*}{ Trauma } & Non-trauma & $9685(62.7 \%)$ & $4210(27.2 \%)$ & $<0.001^{*}$ \\
\hline & Trauma & $741(4.8 \%)$ & 816 (5.3\%) & \\
\hline
\end{tabular}

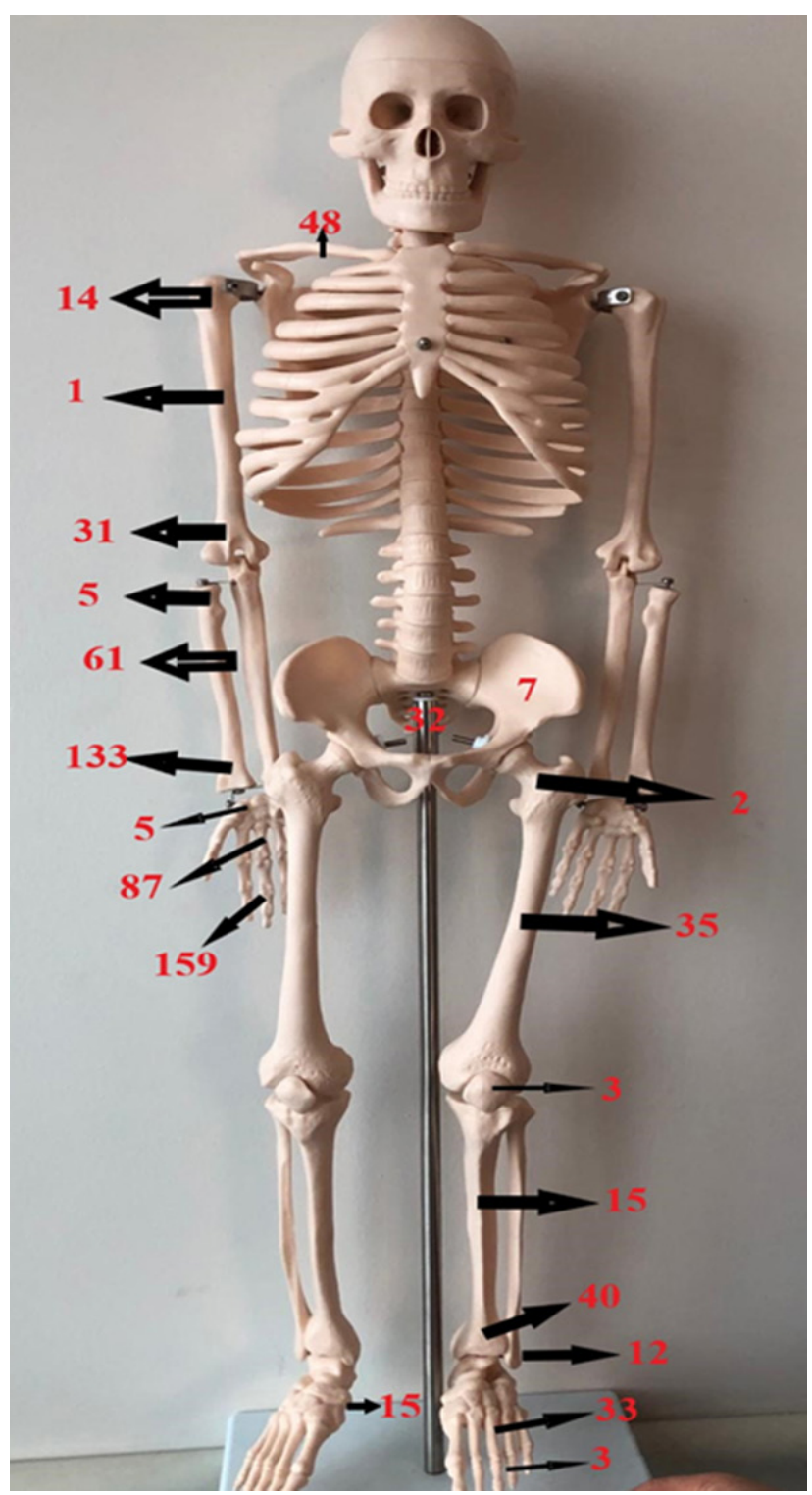

Figure 1. Number of fractures during the Pre-covid period.

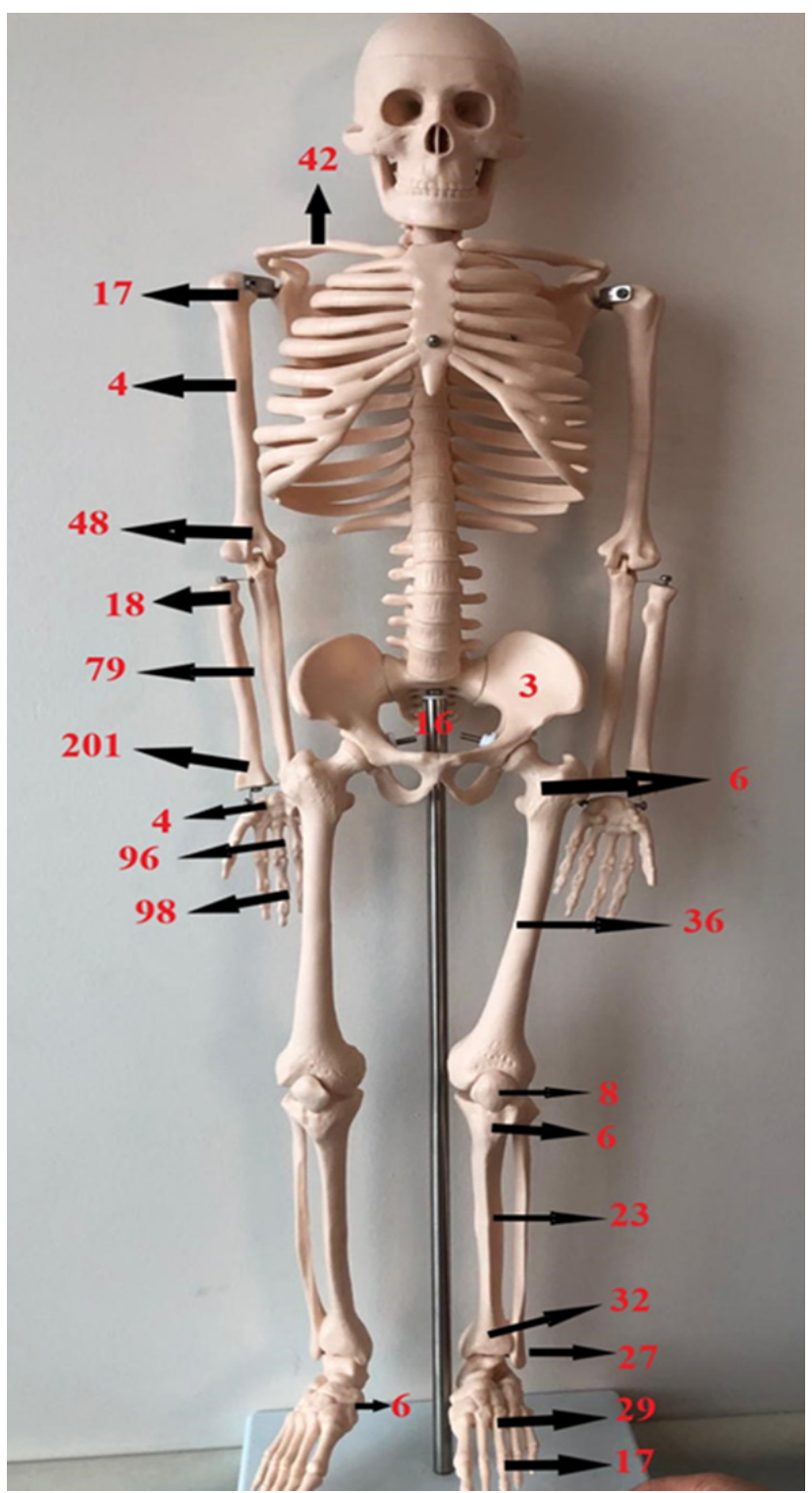

Figure 2. Number of fractures during the Covid period. 
Table 2. Comparison of gender and age groups between trauma and non-trauma cases

\begin{tabular}{|c|c|c|c|c|c|c|}
\hline & & \multicolumn{2}{|c|}{ Non-trauma } & \multicolumn{2}{|c|}{ Trauma } & \multirow[b]{2}{*}{$\mathrm{p}$-value } \\
\hline & & $\begin{array}{c}\text { Pre-covid } \\
\text { Count n (\%) }\end{array}$ & $\begin{array}{c}\text { Covid } \\
\text { Count n (\%) }\end{array}$ & $\begin{array}{c}\text { Pre-covid } \\
\text { Count n (\%) }\end{array}$ & $\begin{array}{c}\text { Covid } \\
\text { Count n (\%) }\end{array}$ & \\
\hline \multirow[t]{2}{*}{ Gender } & Male & 4817 (31.2\%) & 2384 (15.4\%) & $506(3.3 \%)$ & $561(3.6 \%)$ & $<0.001^{\star}$ \\
\hline & Female & 4868 (31.5\%) & $1826(11.8 \%)$ & $235(1.5 \%)$ & $255(1.7 \%)$ & \\
\hline$p$-value & & $<0.001^{\star}$ & & 0.844 & & \\
\hline \multirow[t]{4}{*}{ Age groups } & Children & $1890(12.2 \%)$ & $823(5.3 \%)$ & $374(2.4 \%)$ & $408(2.6 \%)$ & $<0.001^{\star}$ \\
\hline & Young-adult & $4468(28.9 \%)$ & $2215(14.3 \%)$ & $246(1.6 \%)$ & $284(1.8 \%)$ & \\
\hline & Middle-aged & 2291 (14.8\%) & $854(5.5 \%)$ & $84(0.5 \%)$ & 87 (0.6\%) & \\
\hline & Elderly & 1036 (6.7\%) & $318(2.1 \%)$ & $37(0.2 \%)$ & $37(0.2 \%)$ & \\
\hline$p$-value & & $<0.001^{\star}$ & & 0.886 & & \\
\hline
\end{tabular}

Table 3. Distribution of the fracture types between groups

\begin{tabular}{|c|c|c|c|c|}
\hline \multirow[b]{2}{*}{ Fracture types } & \multicolumn{2}{|c|}{ Period } & \multirow[b]{2}{*}{ Total } & \multirow[b]{2}{*}{$\mathrm{p}$-value } \\
\hline & $\begin{array}{l}\text { Pre-covid } \\
\text { Count n (\%) }\end{array}$ & $\begin{array}{c}\text { Covid } \\
\text { Count n (\%) }\end{array}$ & & \\
\hline Coccyx fracture & $32(2.1 \%)$ & $16(1.0 \%)$ & $48(3.1 \%)$ & $<0.001^{*}$ \\
\hline Pelvic ring fracture & $7(0.4 \%)$ & $3(0.2 \%)$ & $10(0.6 \%)$ & $<0.001^{*}$ \\
\hline Clavicle fracture & $48(3.1 \%)$ & $42(2.7 \%)$ & $90(5.8 \%)$ & $<0.001^{*}$ \\
\hline Proximal humeral fracture & $14(0.9 \%)$ & $17(1.1 \%)$ & $31(2.0 \%)$ & $<0.001^{*}$ \\
\hline Humeral diaphysis fracture & $1(0.1 \%)$ & $4(0.3 \%)$ & $5(0.3 \%)$ & 0.001 \\
\hline Distal humeral fracture & $31(2.0 \%)$ & $48(3.1 \%)$ & $79(5.1 \%)$ & $<0.001^{*}$ \\
\hline Proximal radial fracture & $5(0.3 \%)$ & $18(1.2 \%)$ & $23(1.5 \%)$ & $<0.001^{*}$ \\
\hline Forearm diaphysis fracture & $61(3.9 \%)$ & $79(5.1 \%)$ & $140(9.0 \%)$ & $<0.001^{*}$ \\
\hline Distal radial fracture & $133(8.5 \%)$ & $201(12.9 \%)$ & $334(21.5 \%)$ & $<0.001^{*}$ \\
\hline Scaphoid fracture & $5(0.3 \%)$ & $4(0.3 \%)$ & $9(0.6 \%)$ & $<0.001^{*}$ \\
\hline Metacarpal fracture & $87(5.6 \%)$ & $96(6.2 \%)$ & $183(11.8 \%)$ & $<0.001^{*}$ \\
\hline Phalangeal fractures of hand & $159(10.2 \%)$ & $98(6.3 \%)$ & $257(16.5 \%)$ & $<0.001^{*}$ \\
\hline Proximal femoral fracture & $2(0.1 \%)$ & $6(0.4 \%)$ & $8(0.5 \%)$ & $<0.001^{*}$ \\
\hline Femoral shaft fracture & $35(2.2 \%)$ & $36(2.3 \%)$ & $71(4.6 \%)$ & $<0.001^{*}$ \\
\hline Tibia shaft fracture & $15(1.0 \%)$ & $23(1.5 \%)$ & $38(2.4 \%)$ & $<0.001^{*}$ \\
\hline Distal tibia fracture & $40(2.6 \%)$ & $32(2.1 \%)$ & $72(4.6 \%)$ & $<0.001^{*}$ \\
\hline Lateral malleolus fracture & $12(0.8 \%)$ & $27(1.7 \%)$ & $39(2.5 \%)$ & $<0.001^{*}$ \\
\hline Calcaneal fracture & $15(1.0 \%)$ & $6(0.4 \%)$ & $21(1.3 \%)$ & $<0.001^{*}$ \\
\hline Metatarsal fracture & $33(2.1 \%)$ & $29(1.9 \%)$ & $62(4.0 \%)$ & $<0.001^{*}$ \\
\hline Phalangeal fractures of foot & $3(0.2 \%)$ & $17(1.1 \%)$ & $20(1.3 \%)$ & $<0.001^{\star}$ \\
\hline Patella fracture & $3(0.2 \%)$ & $8(0.5 \%)$ & $11(0.7 \%)$ & $<0.001^{*}$ \\
\hline Proximal tibia fracture & $0(0.0 \%)$ & $6(0.4 \%)$ & $6(0.4 \%)$ & NULL \\
\hline Total & $741(47.6 \%)$ & $816(52.4 \%)$ & $1557(100.0 \%)$ & 0.384 \\
\hline
\end{tabular}

n, number.

${ }^{*} p<0.05$.

NULL, test could not be computed because the standard deviation is 0 . 


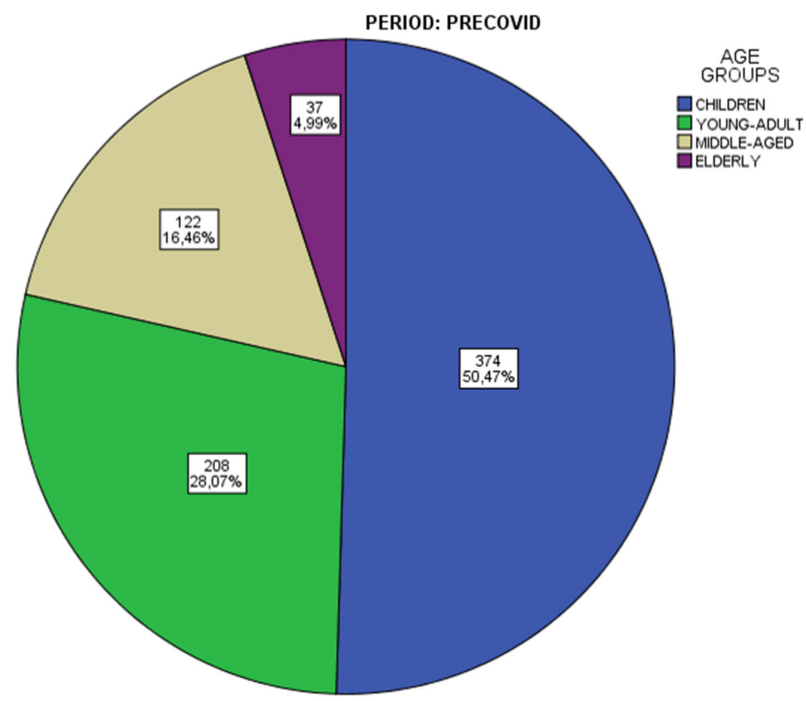

Figure 3. Age groups during the Pre-covid period.

The orthopedic traumas of the patients were examined in 22 subgroups. The most noticeable fracture type was the distal radial fracture, with 334 (21.50\%) patients in total. The second most common type of fracture was the phalangeal fractures of the hand, with $257(16.50 \%)$ patients in total. Statistically significant differences were detected between patients' admission periods and orthopedic trauma causes except for the proximal tibia fractures $(\mathrm{p}<0.001)$. There was no statistically significant difference between the groups regarding the fracture types $(\mathrm{p}=0.384)$. There was no significant difference between the age groups and admission periods $(\mathrm{p}=1.00)$ (Fig. 3 and 4 ).

\section{Discussion}

The Covid-19 outbreak, caused by the Coronavirus- 2 of Severe Acute Respiratory Syndrome (SARSCoV-2), continues to impact societies and medical systems throughout the world ${ }^{4}$. Turkey is one of the countries that strive to decrease the devastating effects of the covid-19 pandemic. Some public health measures have been implemented, such as closing schools and workplaces. People are also afraid to go out. Therefore, we aimed to determine whether indoor injuries would increase and caused changes in the injury pattern in rural areas. Our medical center, which is in a rural location, is the only one in the territory that treats patients with the Covid-19 infection and orthopedic injuries. As a result of these circumstances, we conducted an

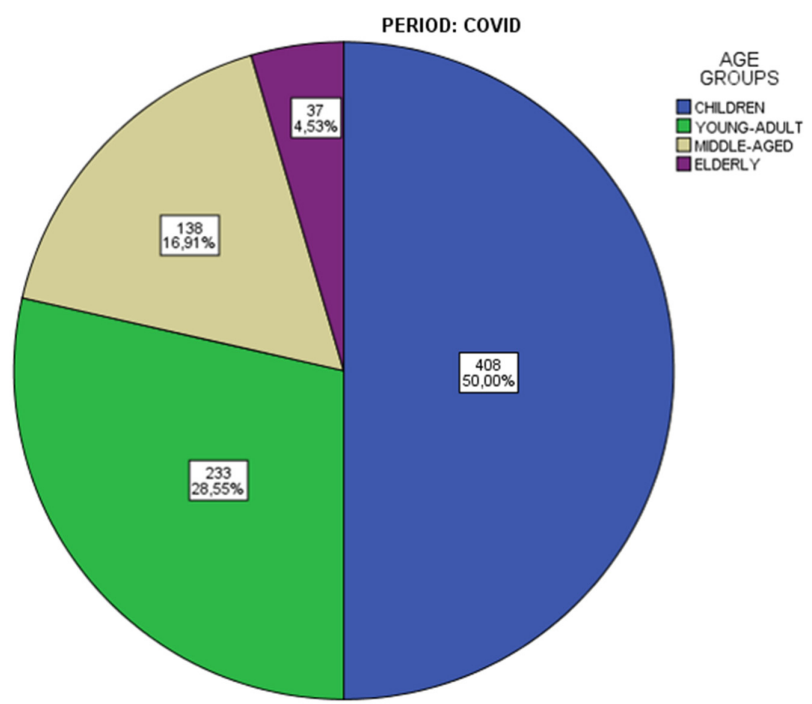

Figure 4. Age groups during the Covid period.

epidemiological study of orthopedic trauma patients. We attempted to evaluate whether the number of traumatic and non-traumatic patients decreased or increased.

Leung et al. ${ }^{5}$ stated that the number of admissions to hospital due to upper and lower extremity fractures decreased due to preventive measures and attempts to "stay home". They also noted that curfew could affect the risk of fracture due to reduced outdoor injuries. In a study from Iran, Kalantar et al. ${ }^{6}$ indicated that the number of referred patients to the emergency room was significantly reduced. They also reported the number of orthopedic operations was also reduced to almost zero in March 2020. Our study found that the number of orthopedic trauma patients admitted to our hospital significantly increased, including upper and lower limb fractures excluding proximal tibia fractures in all populations. This finding was not compatible with the literature. The admission of non-traumatic orthopedic diseases to our outpatient clinic has also decreased significantly. We thought preventive efforts and people's concerns about these potentially contagious illnesses contributed to the decline in the number of patients. Nevertheless, we estimated that household and farmworker injuries increased, increasing traumatic incidents. Another reason was that people could not reach more prominent hospitals in the center because of the prohibition of intercity transportation and the increase in the burden of traumatic cases on our hospital. 
In a study from Iran, they evaluated 628 patients with a mean age of $38.9 \pm 19.9$ (range 1 to 96 ) years who were admitted to the orthopedic emergency departments of two centers, $482(75.30 \%)$ of them were men, and 158 (24.70\%) were women ${ }^{7}$. We evaluated 15452 patients in pre-covid and covid periods; 8268 (53.5\%) were male, and 7184 (46.5\%) were female. The mean age of all groups in our study was $33.90 \pm 20.36$, and it was a younger population than this study.

We determined that distal radius fractures were the most common type of fracture in these two periods. The second most common fracture was phalangeal fractures of the hand. In a recent study, Wong et al. ${ }^{8}$ detected a decrease in the number of patients with orthopedic trauma. Zhu et al. ${ }^{9}$ reported that hip fractures after thoracolumbar fractures were the most common fracture types in the elderly population. In a multi-center study evaluating epidemic and control groups in China, authors determined that femur fractures followed by tibia and fibula fractures were the most common in the Covid-19 group. Femur fractures were also the most common in the control group, but the second most common fracture type was hand and foot fractures ${ }^{10}$. There was no statistically significant difference between fracture type and admission time of the two groups in our study. This outcome was a finding that we did not expect; indoor and outdoor injuries cause different types of fractures, and an increase in indoor injuries would change fracture type. Slullitel et al. ${ }^{11}$ reported that elderly patients were less active and frailer. They also stated that this was associated with higher mortality and affected implant selection. We predicted that elderly patients were expected to be more prone to fractures, particularly the hip and distal radius. However, in our study, we could not find any significant difference between fracture types and age groups.

Because of "stay home" initiatives and special preventive measures for the pediatric group in our country, we detected a decrease in patients admitted to the emergency room or outpatient clinic for fracture treatment. Researchers evaluated the pediatric fractures' epidemiology in a study, and they determined a considerable reduction in lower limb fractures requiring operative treatment ${ }^{12}$. Raitio et al. ${ }^{13}$ found that the number of pediatric fractures decreased 2.5 times during the covid-19 pandemic and stated that this was related to the decline in the usage of playgrounds and the discontinuance of sports activities. Our study was a retrospective study, and we could not categorize injury mechanisms, which was a limitation of our study. Before the Covid-19 outbreak, the amount of pediatric traumatic events treated ineffectively with alternative methods in this territory should not be ignored. Nevertheless, there was an increase in the number of hospitalized pediatric trauma patients. This finding was not consistent with the literature. We predicted that domestic injuries caused a rise in pediatric trauma.

There were some limitations to our study. This study was a retrospective study, and we were unable to categorize injury mechanisms. This study was also limited to a local area. Another limitation was that we evaluated data using ICD-10 codes, so some fractures cannot be detected. Besides, the injury mechanism of patients could not be assessed. The findings would be better if the researchers could examine the multicenter data.

In conclusion, we found an increase in the number of traumatic cases during the covid-19 period compared to the pre-covid period in the rural area of Turkey. However, we did not find any difference in fracture type rates in both groups. Furthermore, we detected a decrease in non-traumatic cases admitted to the outpatient clinic. Our study was the only study achieved in a rural area, evaluating both pre-covid and covid periods. This study suggests that doctors and hospital managers working in rural areas should be prepared for an increase in orthopedic injuries in similar disasters that may occur in the future.

\section{Ethics Committee Approval}

Ethical approval was obtained from the Ethics Committee of Ağri Training and Research Hospital (number: 17, date: 11.11.2020). All procedures in this study involving human participants were performed in accordance with the 1964 Helsinki Declaration and its later amendments.

\section{Informed Consent}

N/A.

\section{Author Contributions}

Concept - S. T. ; Design - S. T., H. Ö. ; Supervision - S. T., O. P. ; Materials - S. T., H. Ö., O. P. ; Data Collection and/or Processing - S. T., H. Ö., O. P. ; Analysis and/or Interpretation - S. T., O. P. ; Literature Search - S. T., H. Ö., O. P. ; Writing Manuscript - S. T. ; Critical Review - S. T., O. P. 


\section{Conflict of Interest}

The authors have no conflicts of interest to declare.

\section{Financial Disclosure}

The authors declared that this study had received no financial support.

\section{References}

1. Zhu N, Zhang D, Wang W, Li X, Yang B, Song J, et al. A Novel Coronavirus from Patients with Pneumonia in China, 2019. N Engl J Med 2020;382(8):727-33.

2. Green MS. Did the hesitancy in declaring COVID-19 a pandemic reflect a need to redefine the term? Lancet 2020;395(10229):1034-5.

3. Nussbaumer-Streit B, Mayr V, Dobrescu A, Chapman A, Persad $\mathrm{E}$, Klerings I, et al. Quarantine alone or in combination with other public health measures to control COVID-19: a rapid review. Cochrane Database Syst Rev 2020(4).

4. Grassi A, Pizza N, Tedesco D, Zaffagnini S. The COVID-19 outbreak in Italy: perspectives from an orthopaedic hospital. Int Orthop 2020;44:1543-7.

5. Leung GM, Cowling BJ, Wu JT. From a sprint to a marathon in Hong Kong. N Engl J Med 2020;382(18): e45.

6. Kalantar S, Farhoud A, Mortazavi J. Lockdown of an Orthopedic Department During COVID-19 Epidemics, Our Experience in a General Hospital. Arch Bone Jt Surg 2020;8(suppl1):235.
7. Khak M, Shakiba S, Rabie H, Naseramini R, Nabian MH. Descriptive Epidemiology of Traumatic Injuries During the First Lockdown Period of COVID-19 Crisis in Iran: A Multicenter Study. Asian J Sports Med 2020;11(2).

8. Wong JSH, Cheung KMC. Impact of COVID-19 on orthopaedic and trauma service: an epidemiological study. J Bone Joint Surg Am 2020;102(14): e80.

9. Zhu Y, Chen W, Xin X, Yin Y, Hu J, Lv H, et al. Epidemiologic characteristics of traumatic fractures in elderly patients during the outbreak of coronavirus disease 2019 in China. Int Orthop 2020;44:1565-70.

10. Lv H, Zhang Q, Yin Y, Zhu Y, Wang J, Hou Z, et al. Epidemiologic characteristics of traumatic fractures during the outbreak of coronavirus disease 2019(COVID-19)in China: A retrospective \& comparative multi-center study. Injury 2020;51(8):1698-704.

11. Slullitel PA, Lucero CM, Soruco ML, Barla JD, Benchimol JA, Boietti BR, et al. Prolonged social lockdown during COVID-19 pandemic and hip fracture epidemiology. Int Orthop 2020;44:1887-95.

12. Bram JT, Johnson MA, Magee LC, Mehta NN, Fazal FZ, Baldwin $\mathrm{KD}$, et al. Where have all the fractures gone? The epidemiology of pediatric fractures during the COVID-19 pandemic. J Pediatr Orthop 2020;40(8):373-9.

13. Raitio $A$, Ahonen $M$, Jääskelä $M$, Jalkanen J, Luoto $T$, Haara $\mathrm{M}$, et al. Reduced number of pediatric orthopedic trauma requiring operative treatment during COVID-19 restrictions: a nationwide cohort study. Scand J Surg 2020:1-4. 